Mr Zoran Novaković, major, dipl. inž. Zoran Milojević, poručnik, dipl. inž.

$$
\text { COLo, }
$$$$
\text { Kruševac }
$$

\section{PROGRAMSKI PAKET ZA REALIZACIJU
PROCENE PROFESIONALNOG RIZIKA NA \\ PROGRAMSKI PAKET ZA REALIZACIJU
PROCENE PROFESIONALNOG RIZIKA NA RADNOM MESTU}

UDC: $331.103 .15: 004.4$

Rezime:

Zakon o bezbednosti i zdravliu na radu donosi niz novih obaveza poslodavaca, među kojima se, po značaju i složenosti, izdvajaju aktivnosti vezane za izradu Akta o proceni rizika na svim radnim mestima. Inicijalizacija projekta izrade softverskog paketa za procenu rizika na radnom mestu i u radnoj okolini izvršsena je na osnovu iskazane potrebe, proistekle iz značajnih zakonodavnih promena koje su donete u oblasti bezbednosti i zdravlja na radu. To predstavlja osnovu za dalju nadgradnju u smislu integralnog informatičkog rešenja za vođenje poslova bezbednosti i zdravlja na radu.

Ključne reči: profesionalni rizik, procena rizika, faktori rizika, softverski paket.

\title{
SOFTWARE PACKAGE FOR RISK ASSESSMENT IN THE WORKPLACE
}

Summary:

A new national Occupational and Safety Law brings many new obligations for employers and among them activities related to risk assessment procedures. A project of developing a software package for conducting a risk assessment procedure in the workplace and in the work environment was initiated, based on needs generated by significant legislation changes in the domain of occupational safety and health. All of previous should be a basis for further upgrading to the level of an integrated software solution in the domain of occupational safety and health.

Key words: professional risk, risk assessment, risk faktors, software package.

\section{Uvod}

Primena informacione tehnologije $\mathrm{u}$ upravljanju, odnosno komandovanju, veoma je aktuelna i značajna. Obrada podataka i njihovo analiziranje jeste oblast $\mathrm{u}$ kojoj informaciona tehnologija nalazi primenu radi skraćenja vremena rada, automatizacije analize, mogućnosti lakog i brzog pretraživanja i pronalaženja potrebnih podataka, čuvanja velikog broja podataka na malom prostoru, mogućnosti brze razmene i slanja podataka, bržeg do- bijanja kvalitetnijih informacija za odlučivanje.

Upotrebom informacione tehnologije u realizaciji procene profesionalnog rizika obezbeđuje se racionalnije korišćenje postojećih resursa, ravnomernija opterećenost ljudstva u okviru jedinice i skraćenje vremena za izradu analiza i odlučivanje. Od komercijalnih programskih paketa koji se nalaze u upotrebi najprimereniji za korišćenje je Microsoft Access koji je efikasno poslužio za izradu i formiranje baze podataka. 


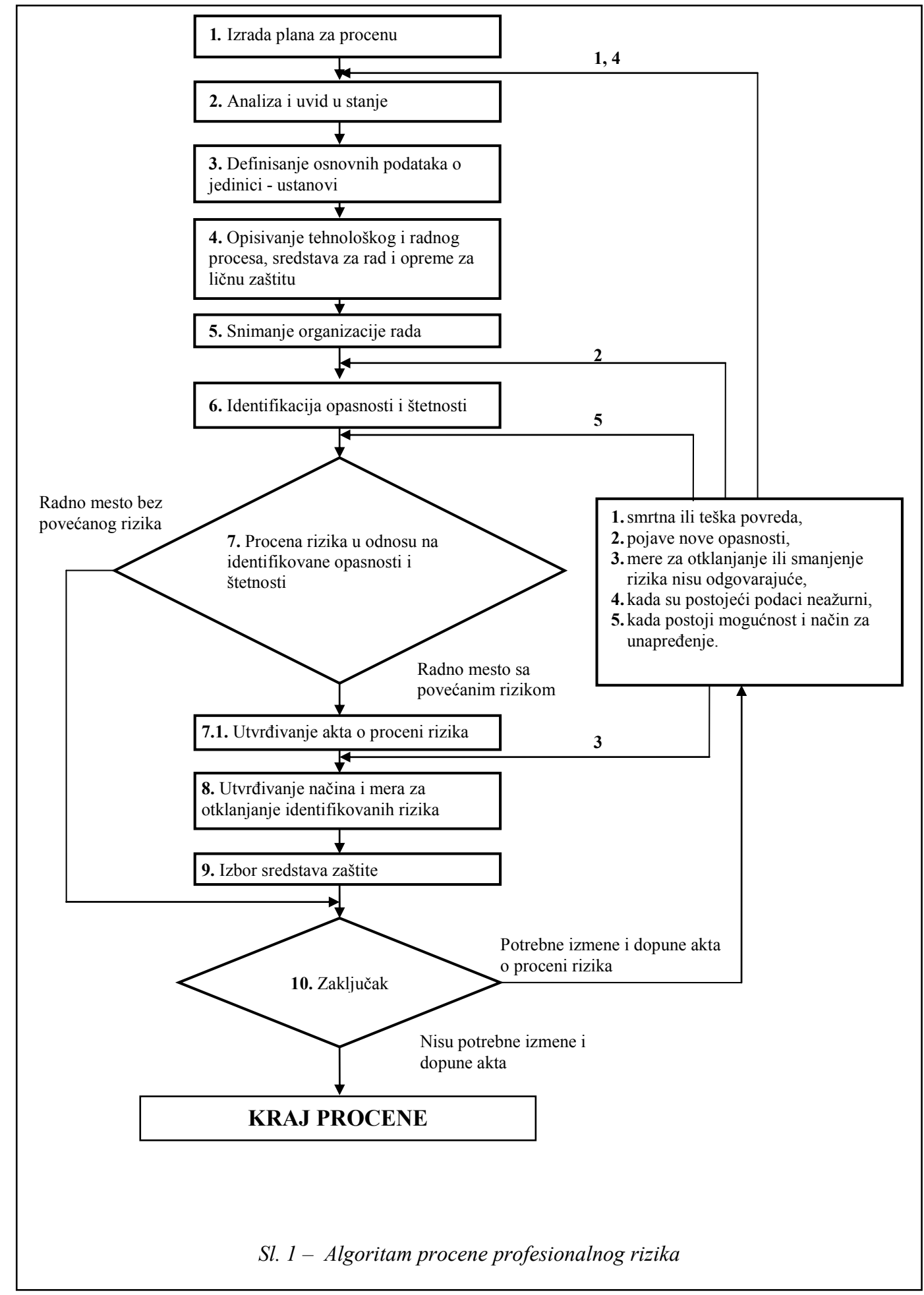




\section{Cilj realizacije programskog paketa}

Cilj utvrđivanja procene profesionalnog rizika je preventivno delovanje $u$ funkciji bezbednosti i zaštite zdravlja zaposlenih, tj. preduzimanje opštih i posebnih mera zaštite na radu radi eliminisanja opasnosti ili štetnosti, ili smanjivanja vremena ekspozicije zaposlenog određenim faktorima rizika $\mathrm{u}$ sredinama gde je ustanovljena njihova prisutnost.

Osnovni cilj realizacije programskog paketa bio je da se, na osnovu pozitivnih iskustava $\mathrm{i}$ analize sličnih programskih paketa, a imajući u vidu specifične zahteve i potrebe potencijalnih korisnika, izvrši projektovanje i razrada programa koji će služiti kao pomoćni alat i vodič za formiranje odgovarajućih baza podataka iz oblasti bezbednosti i zdravlja na radu i sprovođenje zakonom predviđene procedure procene rizika [1].

Program se zasniva na primeni ekspertske procene profesionalnog rizika uz dodatak određenih specifičnosti koje su karakteristične za rad na konkretnim borbenim sredstvima. Bez obzira na to, program se može upotrebiti za specifičnosti rada i na drugim borbenim ili tehničkim sredstvima, uz prethodno realizovanu ekspertsku ocenu. Program omogućava automatsku obradu procenjenih faktora rizika na pojedinim radnim mestima $\mathrm{i}$ njegovu kategorizaciju, odnosno izdvajanje radnih mesta sa povećanim rizikom.

Pomoću programa može se postići bolji učinak referenata zaštite resursa, što se direktno odražava na borbenu gotovost jedinice.

\section{Procedura procene profesionalnog rizika}

Proces donošenja procene profesionalnog rizika zasniva se na algoritmu prikazanom na slici 1 , koji je izrađen na osnovu Pravilnika [2].

\section{Baza podataka}

Baza podataka zasnovana je na unosu i obradi podataka vezanih za realizaciju procene profesionalnog rizika. Projektovana je na način da se zadovolje zahtevi i procedura definisani Pravilnikom [2].

Zbog sveobuhvatnosti realizacije procene profesionalnog rizika bilo je potrebno: uraditi bazu podataka za sva radna mesta; kategorisati radna mesta; utvrditi radna mesta sa povećanim rizikom. Krajnji cilj jeste snimanje stanja na svakom radnom mestu, radi bezbednosti i zdravlja na radu i povećanja borbene gotovosti jedinice.

\section{Postupak procene rizika korišćenjem programskog paketa}

Posle izvršenog projektovanja strukture podataka formiran je glavni (početni) meni (slika 2), koji daje mogućnosti ulaska u podmenije: lista faktora rizika, organizacije, kategorija radnih mesta i kraj rada.

Podmeniji (tabele) međusobno se povezuju da bi podaci iz jednog bili dostupni u drugoj. Veze ili relacije između tabela uspostavljene su tako da više tabela deli istu vrednost. 


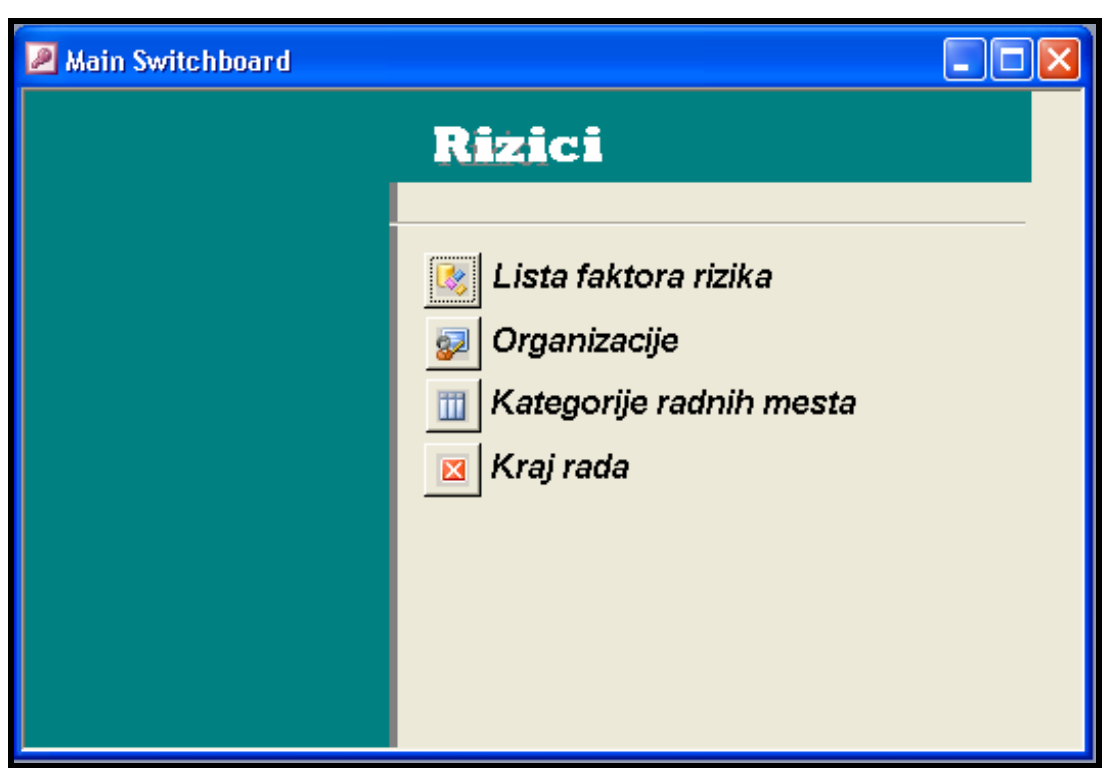

Sl. 2 - Prikaz osnovnog menija

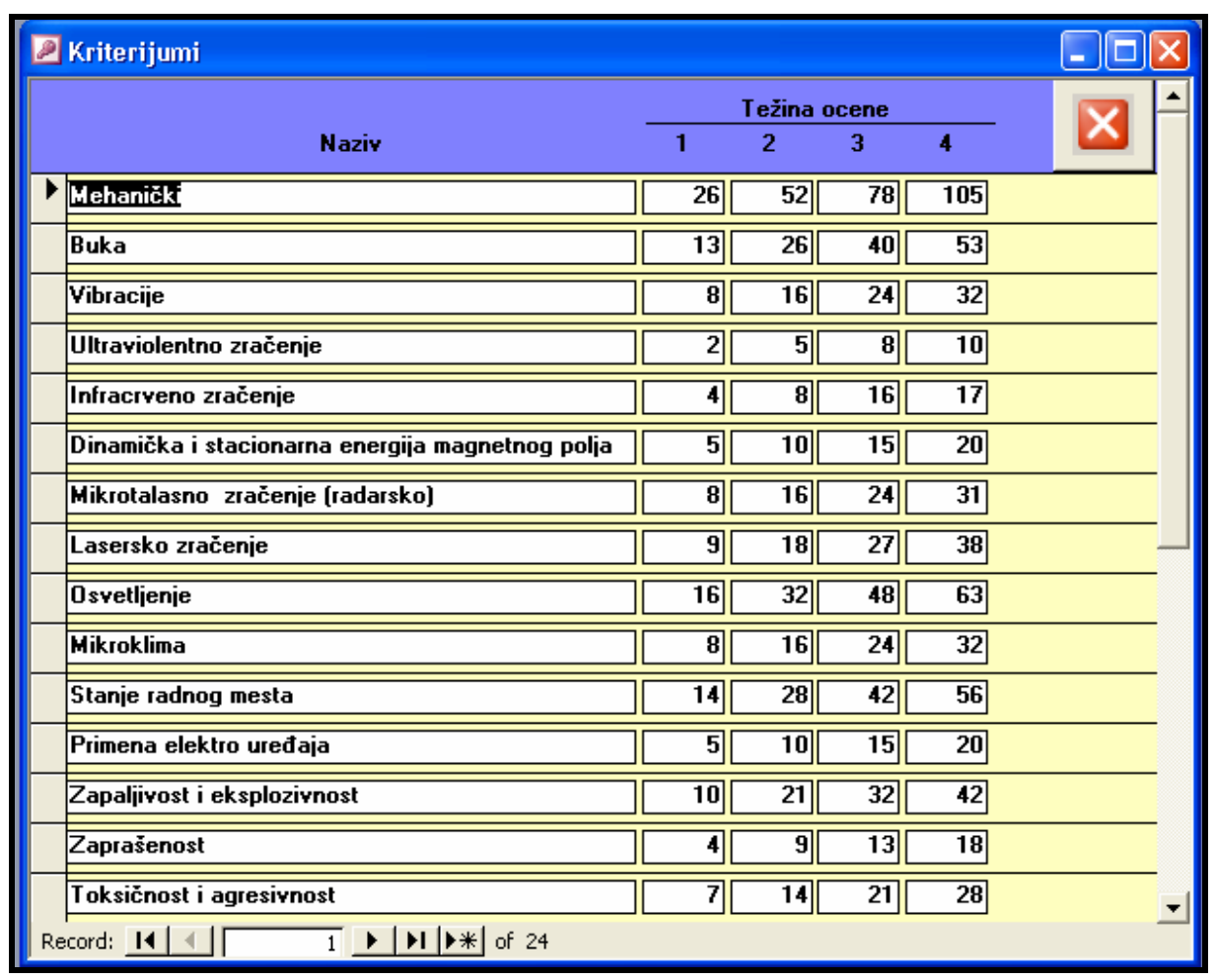

Sl. 3 - Prikaz podmenija - liste faktora rizika 


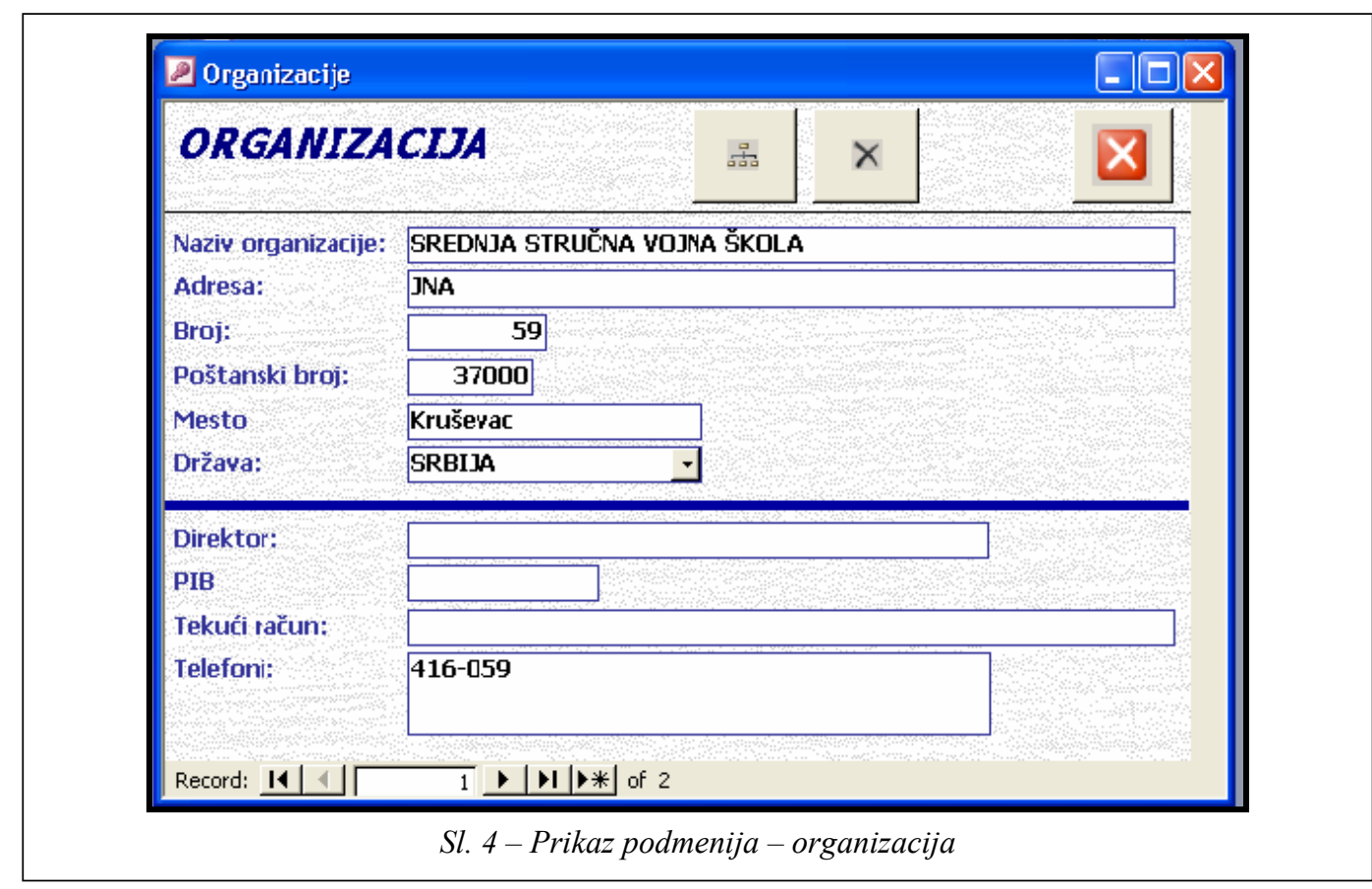

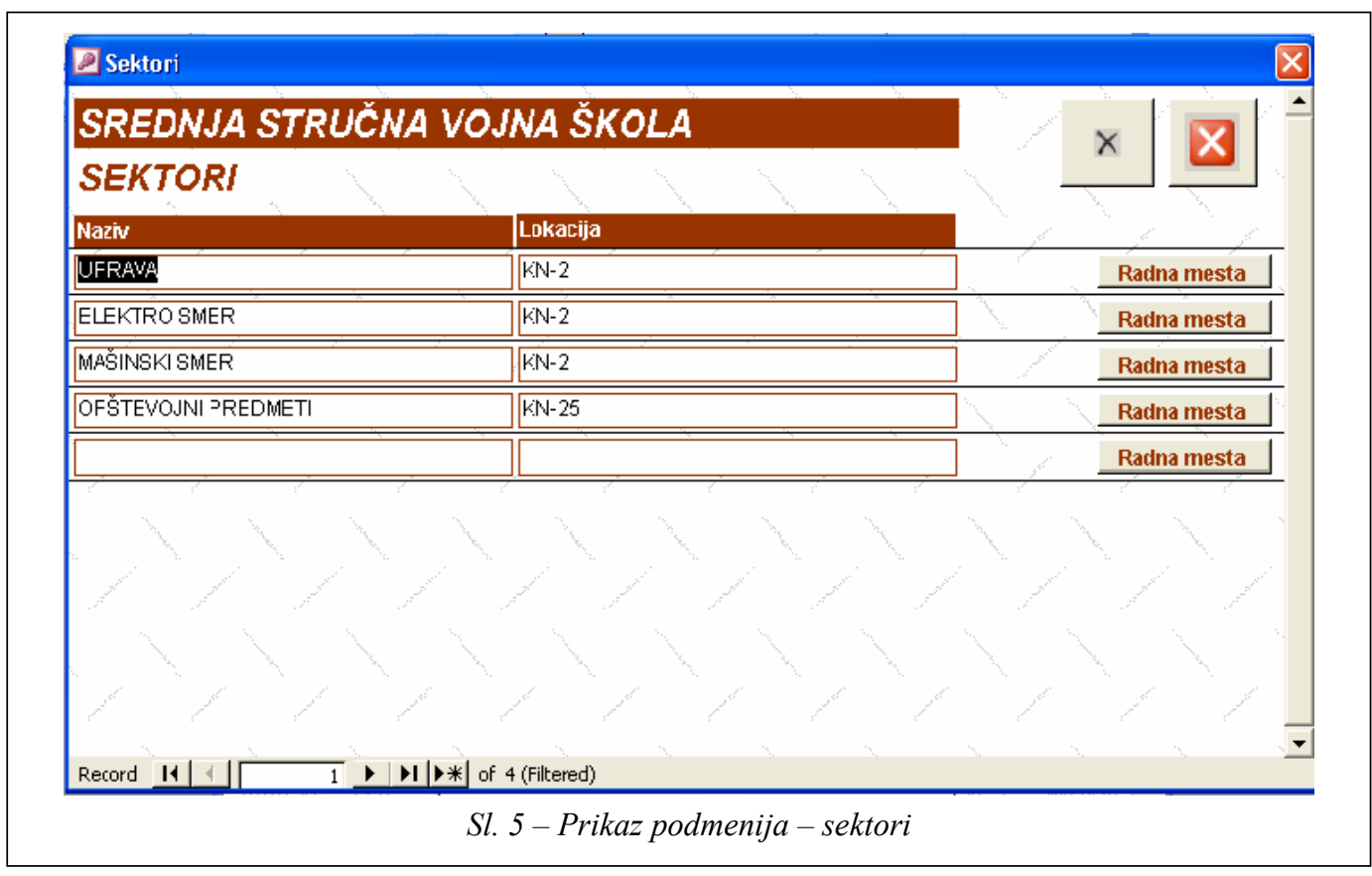

Ulaskom u podmeni (tabelu) Lista faktora rizika počinje aktivan rad. Pojavljuje se tabela za unos podataka u bazu (slika 3), koja se sastoji od jednog lista (u ovom slučaju 24 faktora rizika). Na osnovu ove tabele ocenjivanju se pridru- 


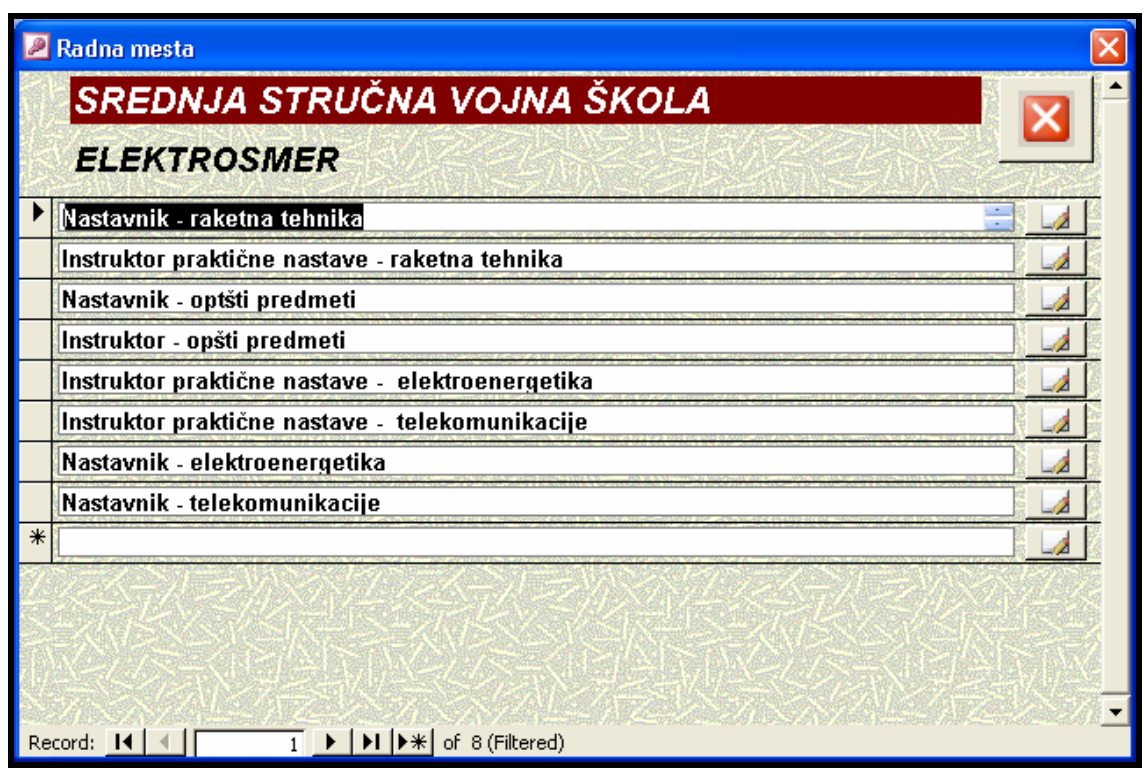

Sl. 6 - Prikaz jedne organizacione celine

\begin{tabular}{|c|c|c|c|}
\hline Ocene za radno mesto & nima & & $x$ \\
\hline SREDNJA STRL & JNA ŠKOLA & & \\
\hline ELEKTROSMER & & & \\
\hline Instruktor praktične & lektroenergetika & & \\
\hline Mehanički & & 3ิ-1 & \\
\hline Buka & & $2=$ & \\
\hline Vibracije & & 15 & \\
\hline Ultraviolentno zračenje & & $2=$ & \\
\hline Infracrveno zračenje & & $2+$ & \\
\hline Dinamička i stacionarna er & nog polja & $2=$ & \\
\hline Mikrotalasno zračenje (rac & & 15 & \\
\hline Lasersko zračenje & & $2=$ & \\
\hline Osvetljenje & & $2+$ & \\
\hline Mikroklima & & 0 -1 & \\
\hline Stanje radnog mesta & & $1+$ & \\
\hline Primena elektro uređaja & & $2 y$ & \\
\hline C - kategorija & UKUPNO BODOVA: & 369 & \\
\hline Komentar: & & & \\
\hline & द. & X & \\
\hline
\end{tabular}

Sl. 7 - Prikaz tabele za realizaciju ocenjivanja profesionalnog rizika na radnom mestu 


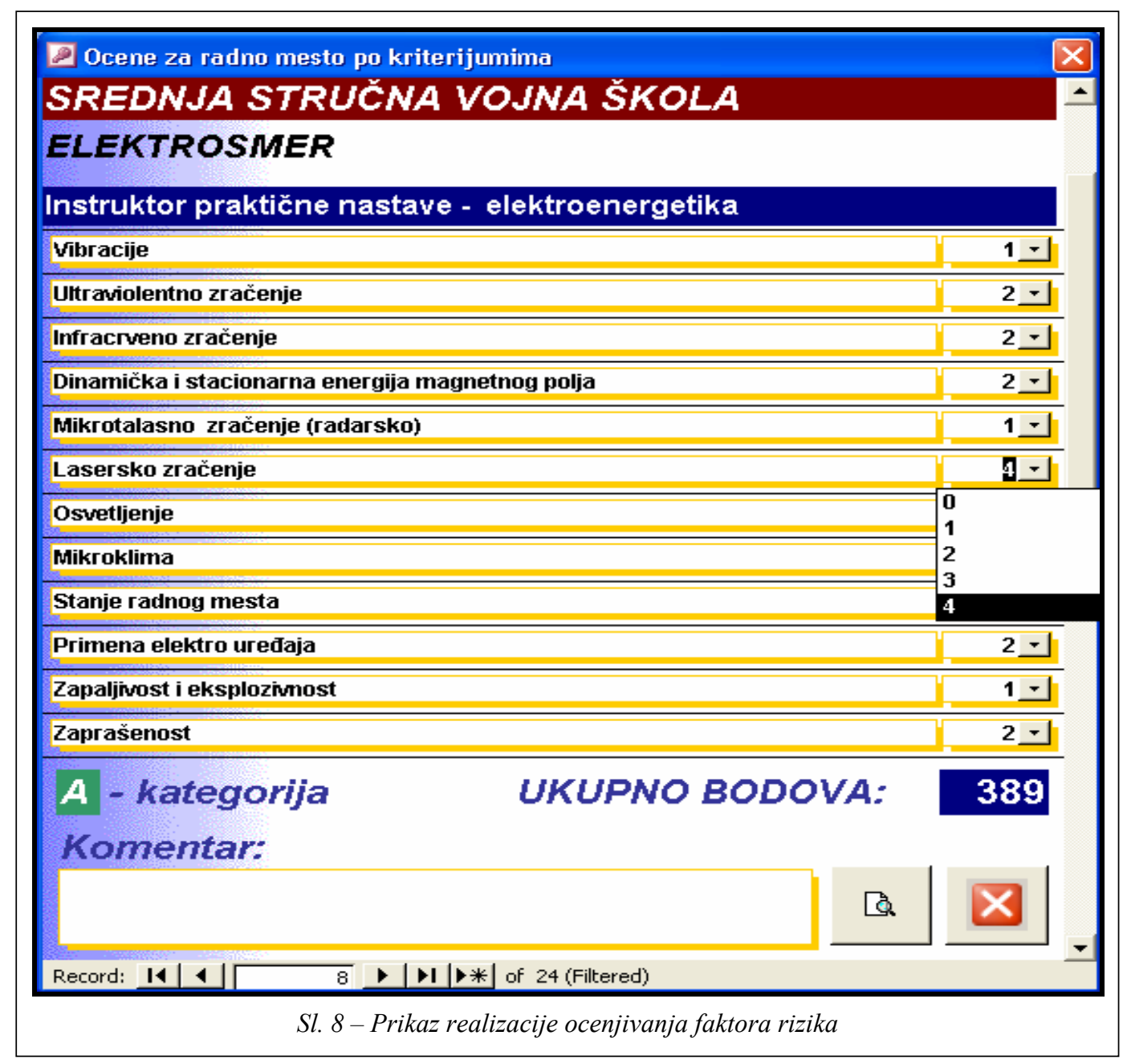

žuje procena faktora rizika sa određenim brojem bodova. Broj bodova je dobijen primenom ekspertske procene profesionalnog rizika za rad na konkretnim radnim mestima vezanim za primenjene oblike nastave i obuke na borbenim sredstvima, karakteristične za posmatranu organizaciju (opširnije u [3] i [4]).

Ulaskom u drugi podmeni Organizacije (slika 4), na ekranu se pojavljuje maska za unos podataka vezanih za osnovne podatke organizacije (jedinice). Mogu se unositi podaci za više organiza- cionih celina, s tim što se mora voditi računa o prethodnoj tabeli koja je karakteristična za jednu celinu.

U okviru prozora Organizacije data je mogućnost unosa strukture organizacije (formacije jedinica). Pritiskom na dugme desno od natpisa organizacija, ulazi se u sledeći podmeni sektor, u koji se unosi naziv organizacionih celina posmatrane organizacije.

U okviru posmatrane celine - sektora mogu se uneti radna mesta za koja će se vršiti procena rizika i to pritiskom na dug- 


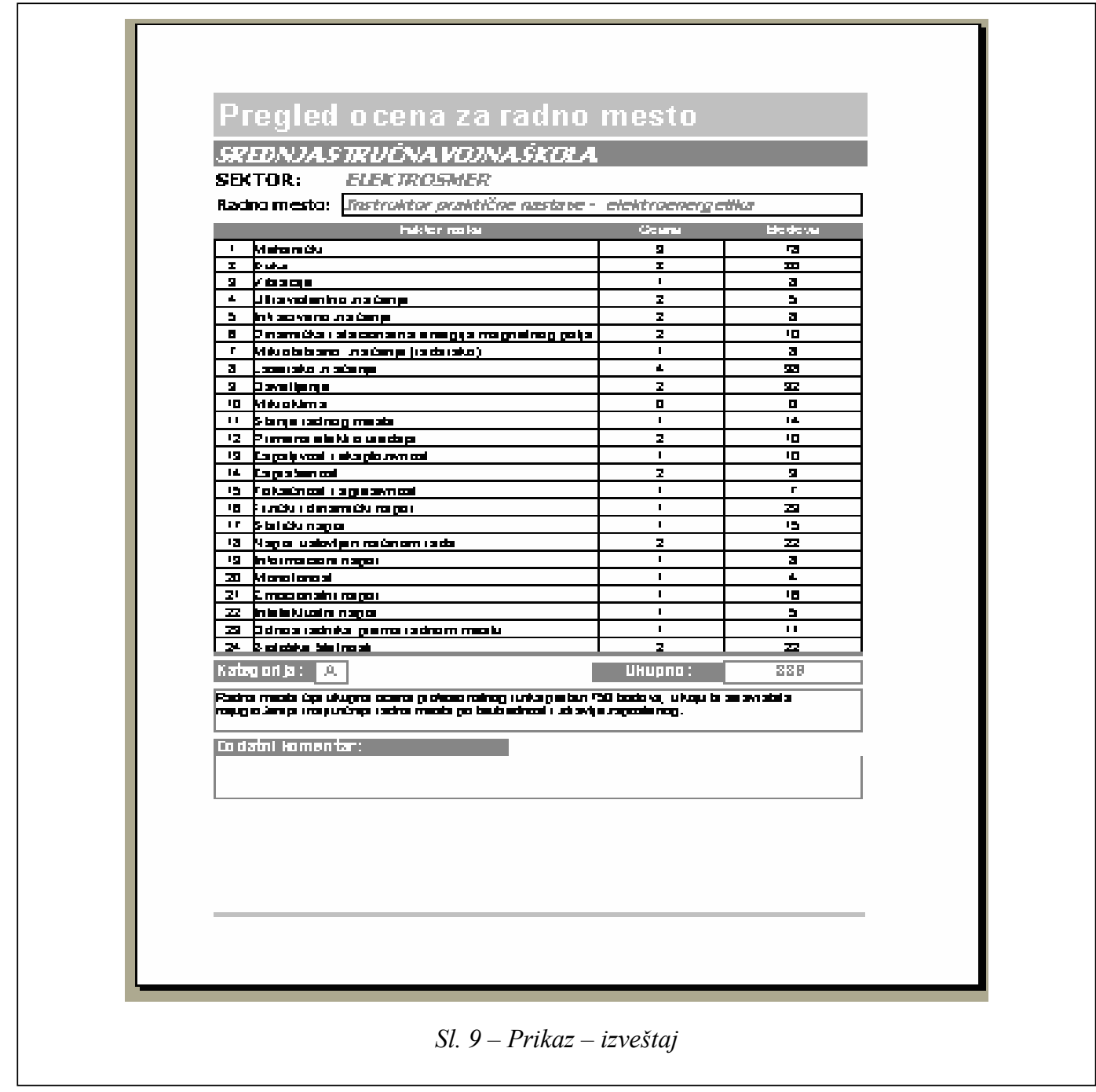

me desno od naziva i lokacije posmatrane celine - sektora. U datom slučaju (slika 6) posmatraju se radna mesta u okviru Srednje stručne vojne škole, smera TSl.

Pritiskom na dugme koje se nalazi desno od naziva radnog mesta program otvara sledeću tabelu (slika 7). Na slici su prikazani, u padajućem nizu, faktori rizika sa ponuđenim procenama od 0 do 4. Na osnovu iskustva ocenjivač vrši procenjivanje svakog pojedinačnog faktora rizika. Program automatski pridružuje ocenu sa određenim brojem bodova koji su prethodno uneti, (tabela na slici 3), vrši sabiranje i automatski obavlja kategorizaciju posmatranog radnog mesta prema kategorijama prikazanim na slici 10 .

U slučaju da na radnom mestu, po proceni procenjivača, deluje faktor rizika ocenjen ocenom 4, automatski se, bez obzira na ukupan iznos bodova, radno mesto kategoriše kao A. 


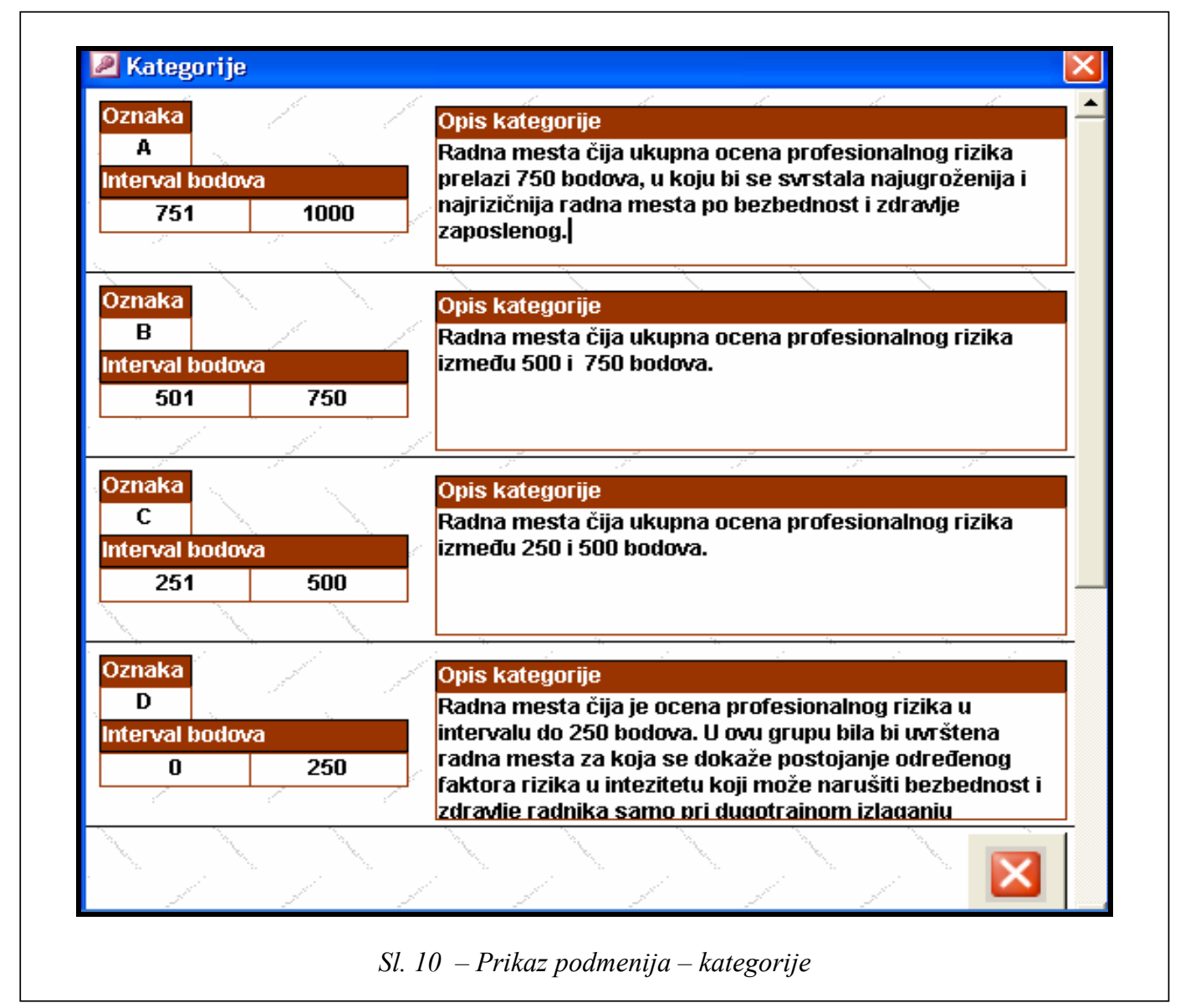

U okviru procene radnog mesta program nudi upis, u vidu komentara, specifičnosti za posmatrano radno mesto, kao na primer: potreba za primenom sredstava lične zaštite, primena posebnih mera zaštite, itd.

$\mathrm{Na}$ kraju ocenjivanja za svako radno mesto može se odštampati izveštaj sa upisanim komentarom za posmatrano radno mesto i komentarom koji je karakterističan za radna mesta kategorije u koju je svrstano radno mesto. Izveštaj je prikazan na slici 9.

Ulaskom u podmeni kategorije (slika 10) na ekranu se otvara prozor koji nudi mogućnost unosa definisanja kate- gorija po kojima će program da vrši kategorizaciju i svrstavanje radnih mesta. U ovom slučaju data je četvorostepena skala za realizaciju kategorizacije radnih mesta na osnovu predloženog i sprovedenog ekspertskog ocenjivanja.

\section{Zaključak}

Programski paket obezbeđuje obradu dela podataka i dobijanje izveštaja radi olakšavanja završne analize i donošenja procene rizika za posmatrano radno mesto. Dobijanje izveštaja za sva radna mesta u posmatranoj organizacionoj celini predstavlja bitno unapređenje u radu. 
Jednu od najvažnijih karakteristika softverskog paketa predstavlja funkcija koja omogućava veoma brzo i automatsko generisanje dokumenta o sprovedenoj proceni rizika u kompletnoj ili skraćenoj formi. Time se ispunjava zakonska obaveza vezana za izradu akta o proceni rizika u pisanoj formi [1]. Dodatna prednost korišćenja softverskog paketa za izradu procene rizika u odnosu na konvencionalne metode predstavlja znatno olakšan rad u fazi revizije i dopune prethodno sprovedenog postupka. Sve unete promene se automatski pohranjuju u bazama podataka, a štampanje izmenjenog oblika dokumenta je brzo i jednostavno.

Treba naglasiti da je program rađen namenski za jedinicu, da predstavlja prvu verziju i da je samo deo procesa procene profesionalnog rizika. Takođe, mogao bi se poboljšati za potrebe posmatrane jedi- nice u kojoj je razvijen i uopštiti, kako bi mogle da ga koriste i druge organizacione celine.

\section{Literatura:}

[1] Zakon o bezbednosti i zdravlju na radu, Službeni glasnik RS, broj 101/05.

[2] Pravilnik o načinu i postupku procene rizika na radnom mestu i u radnoj okolini, Službeni glasnik RS, broj 72/06.

[3] Novaković, Z.: Modeli za ocenu profesionalnog rizika borbenih sistema, Magistarska teza, Fakultet zaštite na radu, Niš, 2007.

[4] Novaković, Z.: Primena metoda ekspertskog ocenjivanja pri oceni profesionalnog rizika, Vojnotehnički glasnik, број 3/07, MO RS, Beograd, 2007.

[5] Anđelković, B., Živković, N.: Primena metoda ekspertnog ocenjivanja uticaja tehnoloških sistema na životnu sredinu, Zbornik radova Međunarodne konferencije, Preventivni inženjering i životna sredina, Fakultet zaštite na radu, Niš, 1995.

[6] Janković, Ž.: Elementi za procenu rizika u sistemu Čovek sredstvo rada, Zbornik radova, Fakultet ZNR, Niš, 2004.

[7] Job Safety or Hazard Analysis JSA / JNA: http://www.ccohs.ca/oshanswers/hsprograms/jobhaz.html, http://www.acusafe.com/Hazard Analysis/OSHA_JSA_3071.pdf

[8] Workplace Risk Assessment and Control (WRAC): http://www.sverdrup.com/safety/pha.pdf 